The Effect of Quench Rate on the Toxicity Characteristic Leaching Procedures (TCLP), PCT Durability of Environmental Waste Glass

by

C. A. Cicero

Westinghouse Savannah River Company

Savannah River Site

Aiken, South Carolina 29808

D. F. Bickford

A. R. Jurgensen

J. L. Resco

Clemson University

SC USA

B. M. Wolff

Clemson University

SC USA

A document prepared for I\&EC SPECIAL SYMPOSIUM

SEVENTH ANNUAL SYMPOSIUM ON EMERGING TECHNOLOGIES IN HAZARDOUS WASTE MANAGEMENT at Atlanta from 09/17/95 - 09/20/95.

DOE Contract No. DE-AC09-89SR18035

This paper was prepared in connection with work done under the above contract number with the U.S.

Department of Energy. By acceptance of this paper, the publisher and/or recipient acknowledges the U.S. Government's right to retain a nonexclusive, royalty-free license in and to any copyright covering this paper, along with the right to reproduce and to authorize others to reproduce all or part of the copyrighted paper. 


\section{DISCLAIMIER}

Portions of this document may be illegible in electronic image products. Images are produced from the best available original document. 


\section{DISCLAIMER}

This report was prepared as an account of work sponsored by an agency of the United States Government. Neither the United States Government nor any agency thereof, nor any of their employees, makes any warranty, express or implied, or assumes any legal liability or responsibility for the accuracy, completeness, or usefulness of any information, apparatus, product, or process disclosed, or represents that its use would not infringe privately owned rights. Reference herein to any specific commercial product, process, or service by trade name, trademark, manufacturer, or otherwise does not necessarily constitute or imply its endorsement, recommendation, or favoring by the United States Government or any agency thereof. The views and opinions of authors expressed herein do not necessarily state or reflect those of the United States - Government or any agency thereof.

This report has been reproduced directly from the best available copy.

Available to DOE and DOE contractors from the Office of Scientific and Technical Information. P. O. Box 62, Oak Ridge, TN 37831; prices available from (615) $576-8401$.

Available to the public from the National Technical Information Service. U. S. Department of Commerce, 5285 Port Royal Rd., Springfield, VA 22161 
PREPRINT EXTENDED ABSTRACT

Presented at the I\&EC Special Symposium

American Chemical Society

Atlanta, GA, September 17-20, 1995

\title{
THE EFFECT OF QUENCH RATE ON THE TCLP AND PCT DURABHITY OF ENVIRONMENTAL WASTE GLASS
}

\author{
J.L. Resce and B.M. Wolff \\ Environmental Systems Engineering Department \\ Clemson University, Clemson, SC 29634 \\ A.R. Jurgensen, C.M. Cicero, and D.F. Bickford \\ Westinghouse Savannah River Company \\ Aiken, SC 29808
}

The effect of quench rate and the resulting devitrification on the durability of environmental waste glasses has been examined for a set of 16 model glasses. The glasses have been derived from a large glass composition space, i.e. "hyperspace glasses," which were previously developed to serve as a simplified model for studying the durability of glassy wasteforms which might result from vitrification. ${ }^{1}$ In this study, a subset of this space has been examined for chemical durability by both the PCT and TCLP tests. This subspace is composed of six variable components $\mathrm{Fe}_{2} \mathrm{O}_{3}, \mathrm{SiO}_{2}, \mathrm{Al}_{2} \mathrm{O}_{3}$, $\mathrm{B}_{2} \mathrm{O}_{3}, \mathrm{Na}_{2} \mathrm{O}$, and $\mathrm{CaO}$ and three fixed-level components $\mathrm{BaO}, \mathrm{PbO}$, and $\mathrm{NiO}$. The sum of the six variable oxides always total to 95 mole percent, while, $\mathrm{BaO}$ and NiO levels are fixed at 2 mole percent each and $\mathrm{PbO}$ is 1 mole percent. The preparation and characterization of these glasses has been previously described. ${ }^{2}$ Their approximate oxide composition, in mole percent, is given in Table 1. These glasses can be classified into two groups, those with low and those with higher levels of $\mathrm{Fe}_{2} \mathrm{O}_{3}$.

The glass melts were cast into molds to produce disks, $40 \mathrm{~mm}$ in diameter by $6 \mathrm{~mm}$ in height. The disks were then quenched at two different rates. Glasses quenched at a medium rate were placed directly into a box furnace at $450^{\circ} \mathrm{C}$ for 30 minutes and the furnace was then turned off. The glasses then cooled to room temperature in about 2 hours. The glasses quenched at a slow rate were placed in a furnace at $650^{\circ} \mathrm{C}$ for 8 hours and then slowly cooled to room temperature. The crystallinity of the glasses was determined by powder $x$-ray diffraction so that they could be classified into three categories: (1) "amorphous," (2) "crystalline," and (3) "more crystalline."

Chemical durability testing was carried out by both the 7-Day Product Consistency Test (PCT) and the TCLP test. The sodium normalized elemental release rate (NaNRR), in $\mathrm{g} \cdot \mathrm{m}^{-2} \cdot \mathrm{d}^{-1}$, was determined from Equation 1 ,

$$
\operatorname{NaNRR}=\frac{\mathrm{C}_{\mathrm{Na}}}{\mathrm{f}_{\mathrm{Na}}\left(\mathrm{SA}_{\mathrm{g}} / \mathrm{V}_{\mathrm{L}}\right) \mathrm{t}}
$$

where $C_{N a}$ is the concentration of elemental sodium in the leachate, in $\mathrm{g} \cdot \mathrm{m}^{-3} ; V_{L}$ is the volume of the leachate; $f_{N a}$ is the weight fraction of sodium in the original glass; $S A_{g}$ is the surface area of the glass; and $t$ is leaching time. The $S A_{g} / W_{L}$ ratio is assumed to be $1950 \mathrm{~m}^{-1}$.

The PCT NaNRR and the TCLP releases of both $\mathrm{Ni}$ and $\mathrm{Ba}$ for both the low and high $\mathrm{Fe}_{2} \mathrm{O}_{3}$ glasses are reported in Figures 1 and 2, respectively. These results show that there is almost no devitrification with either quench rate for the low iron glasses and that there is negligible change in durability. For the high iron glasses, however, some of the slow quenched glasses are significantly more devitrified and crystalline. In some glasses, this increased crystallinity is found to lower the NaNRR and Ba TCLP durability. TCLP Ni release was negligible in both cases. 
TABLE 1. Target Mole Percent Oxide Composition of Glasses"

\begin{tabular}{|c|c|c|c|c|c|c|}
\hline \multirow{2}{*}{ Glass } & \multicolumn{6}{|c|}{ Target Oxide Composition of Glasses, Mole \% } \\
\cline { 2 - 7 } & $\mathrm{SiO}_{2}$ & $\mathrm{Al}_{2} \mathrm{O}_{3}{ }^{\mathrm{b}}$ & $\mathrm{B}_{2} \mathrm{O}_{3}$ & $\mathrm{Fe}_{2} \mathrm{O}_{3}$ & $\mathrm{Na}_{2} \mathrm{O}$ & $\mathrm{CaO}$ \\
\hline $2 \mathrm{LOO}$ & 63 & 0 & 0 & 2 & 10 & 20 \\
$2 \mathrm{LHO}$ & 54 & 0 & 9 & 2 & 10 & 20 \\
$2 \mathrm{LOH}$ & 53 & 10 & 0 & 2 & 10 & 20 \\
$2 \mathrm{LHH}$ & 44 & 10 & 9 & 2 & 10 & 20 \\
$2 \mathrm{HOO}$ & 63 & 0 & 0 & 2 & 20 & 10 \\
$2 \mathrm{HHO}$ & 54 & 0 & 9 & 2 & 20 & 10 \\
$2 \mathrm{HOH}$ & 53 & 10 & 0 & 2 & 20 & 10 \\
$2 \mathrm{HHH}$ & 44 & 10 & 9 & 2 & 20 & 10 \\
\hline $4 \mathrm{LOO}$ & 56 & 0 & 0 & 18 & 7 & 14 \\
$4 \mathrm{LHO}$ & 48 & 0 & 8 & 18 & 7 & 14 \\
$4 \mathrm{LOH}$ & 48.8 & 10 & 0 & 11.6 & 8.2 & 16.4 \\
$4 \mathrm{LHH}$ & 39.8 & 10 & 8.3 & 13.2 & 7.9 & 15.8 \\
$4 H O O$ & 56 & 0 & 0 & 18 & 14 & 7 \\
$4 H H O$ & 48 & 0 & 8 & 18 & 14 & 7 \\
$4 H O H$ & 49.5 & 10 & 0 & 10 & 17 & 8.5 \\
$4 H H H$ & 39.5 & 10 & 8.25 & 14 & 15.5 & 7.75 \\
\hline
\end{tabular}

a. $\mathrm{BaO}, \mathrm{PbO}$, and NiO target values held fixed at 2,1 , and 2 mole $\%$, respectively.

b. Glasses contained about $0.5 \%$ higher $\mathrm{Al}_{2} \mathrm{O}_{3}$ than targeted due to leaching from crucibles.

\section{ACKNOWLEDGMENT}

This work was supported by the U.S. Department of Energy, Office of Technology Development (Mixed Waste Integrated Program), under Contract No. DE-AC09-88R18035 and WSRC Subcontract No. AA00900T.

\section{REFERENCES}

1. Resce, J.L.; Ragsdale, R.G.; Overcamp, T.J.; Bickford, D.F.; Cicero, C.A. "The Effect of Chemical Composition on the PCT Durability of Mixed Waste Glasses from Wastewater Treatment Sludges," In Waste Management Conference, '95 Proceedings, Laser Options, Inc. Tucson AR. (1995).

2. Resce, J.L.; Ragsdale, R.G.; Overcamp, T.J.; Jurgensen, A.R.; Cicero, C.A.; Bickford, D.F. "XRF in Environmental Glass Analysis and Vitrification Process Control, Part 1: Sample Preparation and Measurement Precision," in Environmental and Waste Management Issues in the Ceramic Industry II, pp 461-472, Bickford, D.F.; Bates, S.; Jain, V.; Smith, G. (Eds.), The American Ceramic Society, Westerville, OH (1994). 

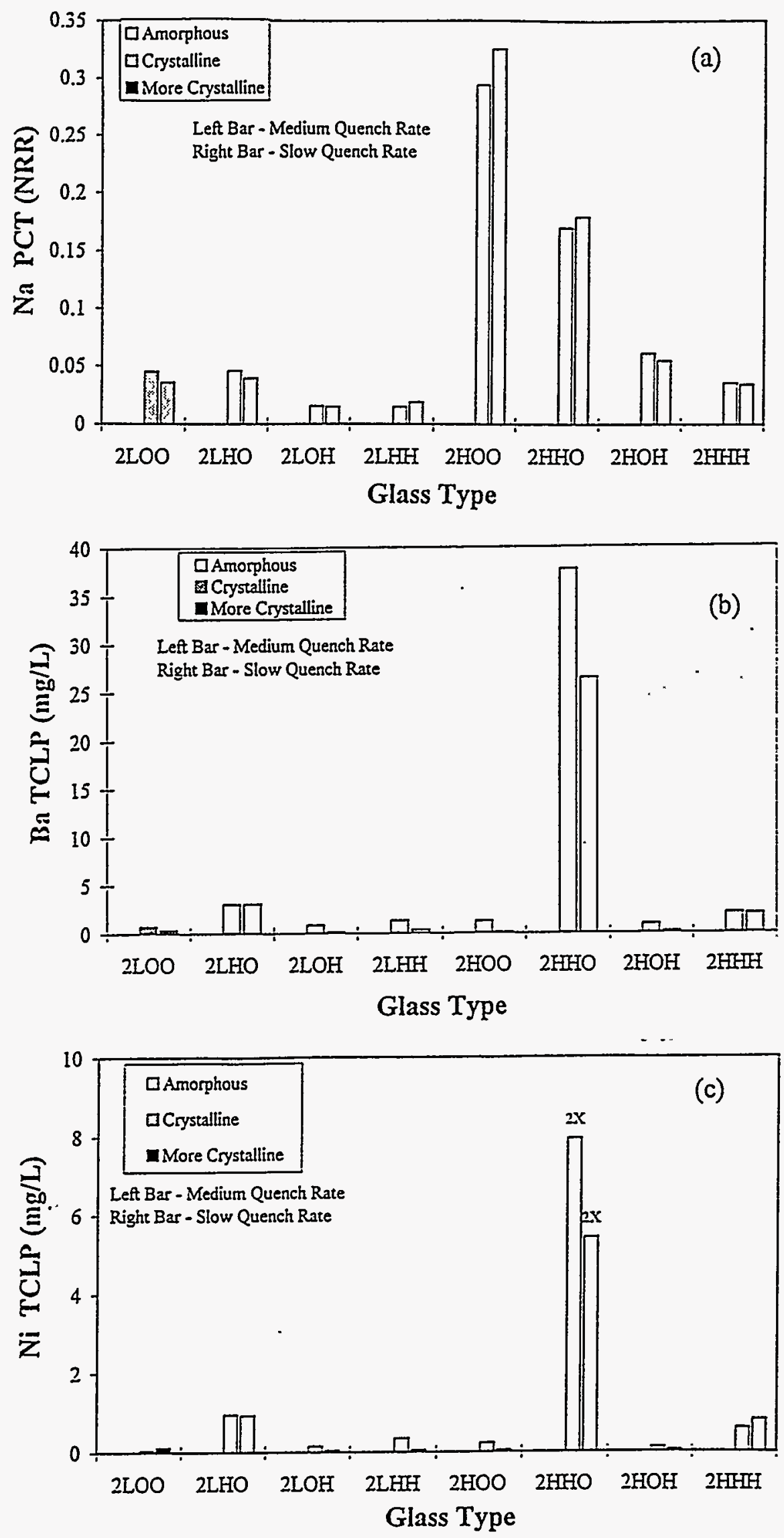

Figure 1: The Effect of Devitrification on the Chemical Durability of Low Iron Glasses; (a) Sodium normalized release rate (Na-NRR) from the Product Consistency Test (PCT) in $\mathrm{g} \cdot \mathrm{m}^{-2} \cdot \mathrm{d}^{-1}$, (b) Barium TCLP release, (c) Nickel TCLP release. 

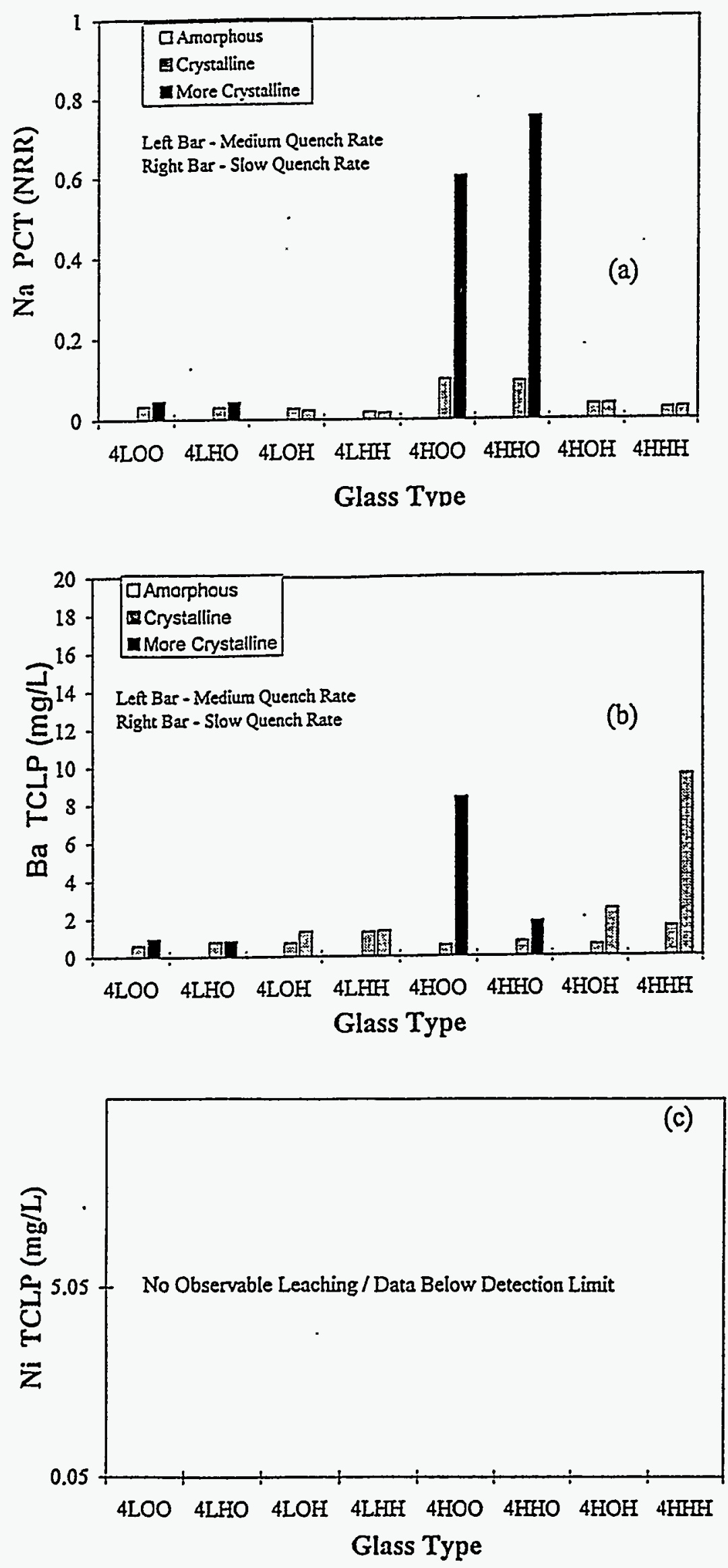

Figure 2: The Effect of Devitrification on the Chemical Durability of High Iron Glasses; (a) Sodium normalized release rate (Na-NRR) from the Product Consistency Test (PCT) in $\mathrm{g} \cdot \mathrm{m}^{-2} \cdot \mathrm{d}^{-1}$, (b) Barium TCLP release, (c) Nickel TCLP release. 